\title{
Familial thrombocytosis
}

INSERM

\section{Source}

INSERM. (1999). Orphanet: an online rare disease and orphan drug data base. Familial thrombocytosis. ORPHA:71493

Familial thrombocytosis is a type of thrombocytosis, a sustained elevation of platelet numbers, which affects the platelet/megakaryocyte lineage and may create a tendency for thrombosis and hemorrhage but does not cause myeloproliferation. 